\title{
Front Matter: Volume 11123
}

, "Front Matter: Volume 11123," Proc. SPIE 11123, Photonic Fiber and Crystal Devices: Advances in Materials and Innovations in Device Applications XIII, 1112301 (1 October 2019); doi: 10.1117/12.2552964

SPIE Event: SPIE Optical Engineering + Applications, 2019, San Diego, California, SPIE. United States 


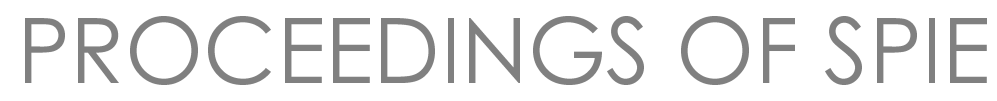

\section{Photonic Fiber and Crystal Devices: Advances in Materials and Innovations in Device Applications XIII}

Shizhuo Yin

Ruyan Guo

Editors

11-12 August 2019

San Diego, California, United States

Sponsored and Published by

SPIE

Volume 11123 
The papers in this volume were part of the technical conference cited on the cover and title page. Papers were selected and subject to review by the editors and conference program committee. Some conference presentations may not be available for publication. Additional papers and presentation recordings may be available online in the SPIE Digital Library at SPIEDigitallibrary.org.

The papers reflect the work and thoughts of the authors and are published herein as submitted. The publisher is not responsible for the validity of the information or for any outcomes resulting from reliance thereon.

Please use the following format to cite material from these proceedings:

Author(s), "Title of Paper," in Photonic Fiber and Crystal Devices: Advances in Materials and Innovations in Device Applications XIII, edited by Shizhuo Yin, Ruyan Guo, Proceedings of SPIE Vol. 11123 (SPIE, Bellingham, WA, 2019) Seven-digit Article CID Number.

ISSN: 0277-786X

ISSN: 1996-756X (electronic)

ISBN: 9781510629394

ISBN: 9781510629400 (electronic)

Published by

SPIE

P.O. Box 10, Bellingham, Washington 98227-0010 USA

Telephone +1 3606763290 (Pacific Time) · Fax +1 3606471445

SPIE.org

Copyright @ 2019, Society of Photo-Optical Instrumentation Engineers.

Copying of material in this book for internal or personal use, or for the internal or personal use of specific clients, beyond the fair use provisions granted by the U.S. Copyright Law is authorized by SPIE subject to payment of copying fees. The Transactional Reporting Service base fee for this volume is $\$ 21.00$ per article (or portion thereof), which should be paid directly to the Copyright Clearance Center (CCC), 222 Rosewood Drive, Danvers, MA 01923. Payment may also be made electronically through CCC Online at copyright.com. Other copying for republication, resale, advertising or promotion, or any form of systematic or multiple reproduction of any material in this book is prohibited except with permission in writing from the publisher. The CCC fee code is $0277-$ $786 \times / 19 / \$ 21.00$.

Printed in the United States of America by Curran Associates, Inc., under license from SPIE.

Publication of record for individual papers is online in the SPIE Digital Library.

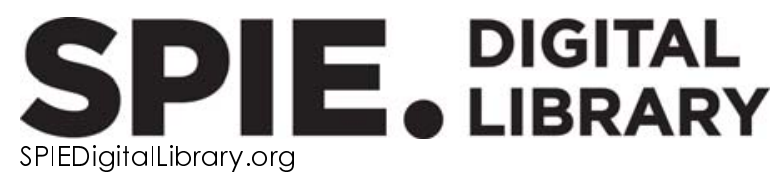

Paper Numbering: Proceedings of SPIE follow an e-First publication model. A unique citation identifier (CID) number is assigned to each article at the time of publication. Utilization of CIDs allows articles to be fully citable as soon as they are published online, and connects the same identifier to all online and print versions of the publication. SPIE uses a seven-digit CID article numbering system structured as follows:

- The first five digits correspond to the SPIE volume number.

- The last two digits indicate publication order within the volume using a Base 36 numbering system employing both numerals and letters. These two-number sets start with 00, 01, 02, 03, 04, 05, 06, 07, 08, 09, 0A, OB ... 0Z, followed by 10-1Z, 20-2Z, etc. The CID Number appears on each page of the manuscript. 


\section{Contents}

$\begin{array}{ll}\vee & \text { Authors } \\ \text { vii } & \text { Conference Committee }\end{array}$

PHOTONIC CRYSTALS, FIBERS, AND THIN FILMS: MATERIALS AND PROPERTIES I

1112302 Luminescent solar concentrators based on polymer nanocomposite films made by open-air pulsed laser deposition (Invited Paper) [1 $11123-1]$

$1112305 \quad$ Ultra-sensitive and large dynamic range refractive index sensor utilizing annular core photonic crystal fiber [1 $11123-5]$

PHOTONIC CRYSTALS, FIBERS, AND THIN FILMS: MATERIALS AND PROPERTIES II

1112307 Small-period titanium-diffused periodically poled lithium niobate waveguides for strongly nondegenerate quantum frequency conversion [1 $11123-6]$

PHOTONIC CRYSTALS, FIBERS, AND THIN FILMS: MATERIALS AND PROPERTIES III

1112309 Performance evaluation of a tunable filter using electro-optic material in metallo-dielectric structures (Invited Paper) [1 $1123-10]$

$111230 \mathrm{~A} \quad$ Force detection using whispering gallery mode-based micro-optical resonators [11123-11]

PHOTONIC CRYSTALS, FIBERS, AND THIN FILMS: DEVICES AND APPLICATIONS I

11123 OD Lasing and supercontinuum generation in single-crystalline fibers (Invited Paper) [11123-14]

PHOTONIC CRYSTALS, FIBERS, AND THIN FILMS: DEVICES AND APPLICATIONS II

$11123 \mathrm{OH} \quad$ A comparison of calibration methods for phase-only LCoS spatial light modulators [11123-19]

PHOTONIC CRYSTALS, FIBERS, AND THIN FILMS: DEVICES AND APPLICATIONS III

11123 OM The study of laser rangefinder with dual branch flexible light guide [1 $1123-24]$ 
11123 ON A smart unmanned aerial system for precision farming management [ $111123-25]$

\section{POSTERS-MONDAY}

11123 OP Effect of relative lattice intensity of Lieb lattice on the propagation of out-of-phase octupole beam [1 11 123-28]

$111230 Q \quad$ Modeling of the refractive index profile of a femtosecond written waveguide in LiNbO3 [11123-29]

11123 OR Research on resonance of fiber nutation [1 $11123-31]$

11123 OS Quantum noise for the propagating solitons in an optical fiber in presence of the third order dispersion coefficient [1 $11123-33]$

11123 OT Deformation measurements using a stereo microscope [1 $1123-34]$

11123 OU Profile measurements using contrast-encoded pattern projections [1 1123-35]

$11123 \mathrm{OV} \quad$ Fourier-transform profilometry using a pulse-encoded fringe pattern [ $111123-36]$

$11123 \mathrm{OW} \quad$ Mask optimization for 1D scanning projected fringe profilometry [11123-37]

$111230 X \quad$ Smart laser weeding system [1 $1123-38]$

11123 OY In-situ characterization of multi-phase flows in a dynamic scraped surface heat exchanger using optical techniques in the visible spectrum [1 $11123-39]$

$111230 Z$ Achieving near-infrared deep tissue imaging via metal organic complex nanoparticles [11123-40]

1112310 A multicomponent GAP-Se chalcogenide composition based rectangular photonic crystal fiber for coherent supercontinuum generation [1 $111123-41]$ 


\section{Authors}

Numbers in the index correspond to the last two digits of the seven-digit citation identifier (CID) article numbering system used in Proceedings of SPIE. The first five digits reflect the volume number. Base 36 numbering is employed for the last two digits and indicates the order of articles within the volume. Numbers start with 00, 01, 02, 03, 04, 05, 06, 07, 08, 09, OA, 0B...0Z, followed by 10-1Z, 20-2Z, etc.

Al-Ghezi, Hammid, 09

Averett, Kent L., OD

Aziz, Muhamad, 02

Banerjee, Partha P., 09

Bezgabadi, A. Safaei, OS

Bolorizadeh, M. A., OS

Bolorizadeh, M., OS

Borhani Zarandi, M., OS

$\mathrm{CaO}$, Liangcai, $\mathrm{OH}$

Chang, Chia-Ying, OX

Chang, Chia-Yuan, OX

Chang, Tsai-Wei, OX

Chang, Yi-Hung, ON

Chauhan, Pooja, 10

Chen, Kan-Shu, OX

Chen, Shean-Jen, $0 X$

Chen, Sih-Yue, ou

Cheng, Nai-Jen, OU, OW

Chou, Shih-Jie, OM

Cook, Gary, OD

Darwish, Abdalla M., 02

Eshel, Ben, OD

Gnawali, Rudra, 09

Guarepi, Valentín, $0 Q$

Hou, Peipei, OR

Hsieh, Cheng-Hsiung, ON

Hsu, Chia-Yu, OW

Hsu, Ken Y., OX

Huang, Tzu-Cheng, OX

Huang, Xin-Ni, OX

Johnson, Michael, 02

Kalra, Yogita, 10

Koplitz, Brent, 02

Kumar, Ajeet, 10

Lee, Long-Jeng, OM

Lee, Yeun Chung, ox

Li, Rujia, $\mathrm{OH}$

Liao, Tai-Shan, OM

Liebig, Carl M., OD

Lin, Hung-Chun, ON

Lin, Yi-An, OW

Liu, Zhi-Hsiang, OV

Lo, Yu-Heng, OT

Lu, Chun-Lin, OX

LU, Zhiyong, OR

McDaniel, Sean A., OD

Mishra, Satyendra K., 05

Patel, Darayas N., 02

Presti, Damián A., $0 Q$
Qin, Yali, OP

Ren, Hongliang, OP

Rubino, Edoardo, OA

Saini, Than Singh, 10

Sarkisov, Sergey S., 02

Sergienko, Alexander V., 07

Sharma, Manish, 05

Shih, Jyun-Yan, ON

Shih, Tzay-Farn, ON

Snyder, John W., 07

Su, Wei-Hung, OT, OU, OV, OW

Sun, Jianfeng, OR

Thompson, Kevin, 02

Torchia, Gustavo A., OQ

Tripepi, Michael, OD

Ung, Bora, 05

Videla, Fabián, $0 Q$

Weng, Tsui-Hsia, OX

Wilson, Jamaya, 02

Wu, Chi-Yuan, OX

$X i$, Yueli, OR

$X U$, Qian, OR

$X \cup e$, Linlin, OP

Yang, Guang, 07

Zhang, Xiaodong, 02

Zhang, Xiaowei, OP

Zhou, Yu, OR

Zittlow, Dustin, OA 
Proc. of SPIE Vol. $111231112301-6$

Downloaded From: https://www.spiedigitallibrary.org/conference-proceedings-of-spie on 26 Apr 2023 Terms of Use: https://www.spiedigitallibrary.org/terms-of-use 


\section{Conference Committee}

Program Track Chair

Ruyan Guo, The University of Texas at San Antonio (United States)

Conference Chairs

Shizhuo Yin, The Pennsylvania State University (United States)

Ruyan Guo, The University of Texas at San Antonio (United States)

Conference Program Committee

Manmohan D. Aggarwal, Alabama A\&M University (United States)

Partha P. Banerjee, University of Dayton (United States)

Liliana Braescu, Institut National de la Recherche Scientifique (Canada)

Liangcai Cao, Tsinghua University (China)

Amol Choudhary, The University of Sydney (Australia)

Ken-Yuh Hsu, National Chiao Tung University (Taiwan)

Rongqing Hui, The University of Kansas (United States)

Suganda Jutamulia, University of Northern California (United States)

Ravindra B. Lal, Alabama A\&M University (United States)

Byoungho Lee, Seoul National University (Korea, Republic of)

Carl M. Liebig, Air Force Research Laboratory (United States)

Sergei F. Lyuksyutov, The University of Akron (United States)

Paul B. Ruffin, U.S. Army Research, Development and Engineering Command (United States)

Narsingh B. Singh, University of Maryland, Baltimore County (United States)

Wei-Hung Su, National Sun Yat-Sen University (Taiwan)

Ching-Cherng Sun, National Central University (Taiwan)

Jun Zhang, U.S. Army Research Laboratory (United States)

Xiang Zhang, University of California, Berkeley (United States)

\section{Session Chairs}

1 Photonic Crystals, Fibers, and Thin Films: Materials and Properties I

Abdalla M. Darwish, Dillard University (United States)

Ruyan Guo, The University of Texas at San Antonio (United States)

2 Photonic Crystals, Fibers, and Thin Films: Materials and Properties II

Abdalla M. Darwish, Dillard University (United States)

Ruyan Guo, The University of Texas at San Antonio (United States) 
3 Photonic Crystals, Fibers, and Thin Films: Materials and Properties III Partha P. Banerjee, University of Dayton (United States)

4 Photonic Crystals, Fibers, and Thin Films: Devices and Applications I Carl M. Liebig, Air Force Research Laboratory (United States)

5 Photonic Crystals, Fibers, and Thin Films: Devices and Applications II Amar S. Bhalla, The University of Texas at San Antonio (United States) Wei-Hung Su, National Sun Yat-sen University (Taiwan)

6 Photonic Crystals, Fibers, and Thin Films: Devices and Applications III Paul B. Ruffin, Alabama A\&M University (United States) Ching-Cherng Sun, National Central University (Taiwan) 